\title{
DISMISSAL PROTECTIONS IN A GLOBAL MARKET: LESSONS TO BE LEARNED FROM SERCO
}

\section{LTD V LAWSON}

\section{INTRODUCTION}

The rise of labour as a transnational phenomenon is an aspect of globalisation. New Zealand law relating to protection from dismissal without cause (unjustifiable dismissal) is failing employers and employees whose employment agreements have international elements. In New Zealand, protection from dismissal without cause is contained in the Employment Relations Act 2000 (NZ). However, the Act is not an 'overriding statute'. Cases, where the facts show the operation of global employment markets, are decided according to conflict of laws rules relating to contracts. The operation of these rules can result in employees being inappropriately excluded from New Zealand dismissal protections. The complexity of the rules makes them inappropriate for the resolution of employment relationship problems, to the detriment of both employers and employees.

Job security is important for full participation in society and there is a strong relationship between employment and identity. New Zealand employment law reflects the position that dismissal 'for cause' is preferable to 'employment-at-will'. In a volatile global market, this is an immensely valuable entitlement for employees and for society, and one that is not universal.

To achieve workable and appropriate protection from unjustifiable dismissal in a global employment market, it is suggested that the Employment Relations Act 2000 (NZ) be amended along the lines of section 204 of the Employment Rights Act 1996 (UK). Additionally, the New Zealand statute should have a provision which states that the Act 
applies to the categories of employee identified by Lord Hoffman in the case of Serco Ltd v Lawson [2006] UKHL 3 (UK).

\section{EMPLOYMENT PROTECTION UNDER NEW ZEALAND LAW}

Protection from unjustifiable dismissal is an important right from which some in the global market may be excluded because they are not covered by the Employment Relations Act 2000 ('ERA 2000'), or because obtaining a ruling that the ERA 2000 applies is too uncertain, complex and costly. The ERA 2000 aims to provide for time-efficient resolution of employment relationship problems, through early access to mediation and reducing the need for judicial intervention. ${ }^{1}$ An 'employee"2 who believes that he or she has a personal grievance (including one of unjustifiable dismissal ${ }^{3}$ ) may pursue that grievance under the Act $^{4}$. A dismissal may only be challenged under the ERA 2000. ${ }^{5}$ An unjustifiable dismissal grievance must be raised firstly with the employer. ${ }^{6}$ If the problem is unresolved then resolution through mediation must be attempted. ${ }^{7}$ The next step is for the employee to apply for a determination by the Employment Relations Authority ('the Authority'), a statutory, specialist institution which is an investigative first-level decision-making body. ${ }^{8}$ Subject to

\footnotetext{
${ }^{1}$ Section 3(a)(v)(vi).

${ }^{2}$ An employee is a person of any age employed by an employer to do any work for hire or reward under a contract of service, as per s 6(1)(a) of the ERA 2000.

${ }^{3}$ ERA 2000 s 103(1)(a).

${ }^{4}$ Ibid, s 102.

${ }^{5}$ Section 113.

${ }^{6}$ ERA 2000, s 114.

${ }^{7}$ Ibid s 159 .

${ }^{8}$ ERA 2000 s 156.

2
} 
restrictions related to cancellation and variation of employment agreements, the Authority can make the same orders as the High Court or District Court may make under any statute or rule of law relating to contracts. ${ }^{9}$ It may not do anything inconsistent with the relevant employment agreement. ${ }^{10}$ It is able to deal with questions of interpretation of the ERA 2000. ${ }^{11}$ One member of the Authority may hear and determine an application. A member of the Authority need not be legally qualified ${ }^{12}$, yet may be dealing with complex law. The matter may be immediately removed to the Employment Court (a statutory, specialist institution) in circumstances where an important question of law is involved, or it is a matter of urgency, or where the court has related proceedings before it, or if the Authority or the Employment Court feels that the matter should be removed. ${ }^{13}$ A determination of the Authority may be challenged before the Employment Court on a question of law or fact. ${ }^{14}$ Appeal to the Court of Appeal is available only on questions of law, and to the Supreme Court on questions of law in exceptional circumstances. ${ }^{15}$

\section{A The Employment Relations Act 2000}

The ERA 2000 is clearly intended to reduce the need for judicial intervention in employment relationship problems. Yet in cases with international elements, the Act (and its predecessor the Employment Contracts Act 1991 (NZ) ('ECA 1991') has been interpreted in such a way that contracts conflict of laws rules apply.

\footnotetext{
${ }^{9}$ Ibid s 162.

${ }^{10}$ Ibid s 157.

${ }^{11}$ Ibid Schedule 2 cl. 1(2).

${ }^{12}$ Ibid ss $156-176$.

${ }^{13}$ Ibid s 178 .

${ }^{14}$ Ibid s 179.

${ }^{15}$ Ibid s 211, 214A.
} 
Section 238 of the ERA 2000 states that the Act's provisions of 'have effect despite any provision to the contrary in any contract or agreement.' This section addresses the inherent inequality of power in employment relationships ${ }^{16}$ by restricting, but not removing, the ability of the parties to 'contract out' of the rights, obligations and remedies provided by the ERA 2000. Section 238 materially re-enacts s 147 of the ECA $1991^{17}$ and s 147 has been interpreted as meaning parties cannot 'contract out' of the protection of New Zealand law by express choice of the 'proper law' if they expressly select as the proper law governing their contract of employment a foreign system of law which has little or no connection with that contract of employment. ${ }^{18}$ As a matter of statutory interpretation, the courts have found that section 238 does not determine the applicability of the Act (the Act is not part of any mandatory rules of employment law $^{19}$ ) but is evidence that the legislature intended that the Act's provisions should not be frustrated by absolute autonomy of choice of law. ${ }^{20}$

While s 238, as interpreted, limits the parties' choice of law, the ERA 2000 does not have a provision that expressly limits the application of the Act in cases with international elements and nor did its predecessor, the ECA 1991. Nor does it expressly state that it applies to all employment agreements with a New Zealand element. The provisions of the Act are broadly expressed, but the presumption against extraterritorial application is used to

\footnotetext{
${ }^{16}$ ERA 2000, s 3(a)(ii).

${ }^{17}$ Section 147 states that ' $[\mathrm{t}]$ he provisions of this Act shall have effect notwithstanding any provision to the contrary in any contract or agreement.'

${ }^{18}$ See specifically Clifford v Rentokil Ltd [1995]1 ERNZ 407, 433-434 (EC).

${ }^{19}$ Dicey and Morris on the Conflict of Laws (1 $1^{\text {th }}$ ed Stevens London 1987) vol. 1, 21, cited in Clifford $v$ Rentokil Ltd [1995] 1 ERNZ 407 (EC), at 433. The approach in Clifford is consistent with the approach of the Court of Appeal in the sovereign immunity case of Governor of Pitcairn and Associated Islands $v$ Sutton [1995] 1 NZLR 426 (CA).

${ }^{20}$ Musashi Pty Ltd v Moore [2002] 1 ERNZ 203 (EC) at 218. 
'qualify the reach of the statute'. ${ }^{21}$ The approach of the Employment Court regarding the application of the Act to employees in global market situations involves conflict of laws rules applicable to contracts. The specialist institutions under both the ECA 1991 and the ERA 2000 have determined that the legislative intention was to restrict the scope of the Act to cases where the proper law of the contract was that of New Zealand, subject to s 147 (now s 238), which Palmer $\mathbf{J}$ describes as a 'fundamental caveat'. ${ }^{22}$ The courts have not accepted that the absence of a specific restriction on the application of the relevant statute means that the statutory dismissal protections will always apply. They treat dismissal protections as contractual.

\section{B New Zealand CaSe law under the Employment Contracts ACt 1991 and the EMPloyment Relations ACt 2000}

There are a number of cases under the ECA 1991 and the ERA 2000 where the facts demonstrate the operation of the global market. The threshold issue in each case was whether the employee was entitled to statutory protection from unjustifiable dismissal, or remedies for wrongful dismissal ${ }^{23}$ Because of the courts' approach to the interpretation of these statutes discussed above, the cases were decided using the following rules that apply to contractual issues in conflict of laws cases:

Contractual issues are governed by the proper law of the contract.

The proper law is determined by applying New Zealand conflict rules.

\footnotetext{
${ }^{21}$ Governor of Pitcairn and Associated Islands v Sutton [1995] 1 NZLR 426,438 (CA).

${ }^{22}$ Clifford v Rentokil Ltd [1995] 1 ERNZ 407 (EC), at 433.

${ }^{23}$ A common law action no longer available by virtue of the ERA 2000, s 113. 
Those rules state that parties can expressly choose the proper law or an implied choice is inferred from the contract and surrounding circumstances.

If determination is not by express or implied choice, then the 'proper law' is that with which the transaction has the closest or most real connection.

The proper law is likely to be the law of the place of performance if the contract is made in one place but is wholly performed by both parties in another place, but where the performance is to be in more than one place, the place of performance takes on less significance.

Where the proper law of the contract is New Zealand law, the ECA 1991 (now, the ERA 2000) will apply to 'offshore work' ${ }^{24}$

The ECA 1991 and the ERA 2000 have been found by the specialist institutions to be procedural statutes which give the specialist institutions exclusive jurisdiction to hear and determine proceedings founded on an employment contract. ${ }^{25}$ These institutions may be forum conveniens or the proceedings may be stayed for a foreign forum conveniens. ${ }^{26}$ Where there is a court in a foreign country which also has jurisdiction to hear and determine the case, the New Zealand court may stay or dismiss the New Zealand proceeding if it considers

\footnotetext{
${ }^{24}$ See specifically Redmond v DML Resources Ltd [1996] 1 ERNZ 448, 463 (EC).

${ }^{25}$ See Royds v FAI (NZ) General Insurance Company Ltd [1999] 1 ERNZ 820 at 834 (EC) where the court held (obiter) that the Employment Court under the ECA 1991, s 104(1)(h) (now s 162 of the ERA 2000) had jurisdiction to hear and determine cases where the proper law of the contract is foreign law. See also Musashi Pty Ltd v Moore [2002] 1 ERNZ 203. It should be noted that in Singapore Airlines Ltd v Rusli, unreported, District Court, Auckland, 12 November 1997, NP1230/97, Judge Joyce set aside a protest to jurisdiction in favour of the Employment Court holding that the statutory institutions have no jurisdiction where foreign law applies and that recourse should be had to a court of general jurisdiction. If the analysis of the District Court is correct, the specialist institutions would lack any jurisdiction. Removal from the specialist employment institutions would have the attendant disadvantages of complexity, delay and increased costs.

${ }^{26}$ The forum conveniens is the forum in which the proceeding could be more suitably tried in the interests of the parties and for the ends of justice: see the Laws of New Zealand vol 7 Conflict of Laws: Jurisdiction on Foreign Judgments, paragraph 26. 
that the foreign court is the natural forum for the trial of the proceeding. A stay will be granted where the defendant satisfies the court that there is another appropriate forum which has competent jurisdiction. The natural forum is that with which the action has the most real and substantial connection in terms of convenience, expense and the proper law. ${ }^{27}$ The law governing the employment agreement is not a determining factor and neither is the place where the work takes place, although there is increasing recognition that disputes should be resolved where the work is carried out. ${ }^{28}$

The facts and outcomes of cases in which above approach to the scope of dismissal protections has been taken are as follows:

Clifford v Rentokil Ltd [1995] 1 ERNZ 407 (EC).

Mr Clifford brought a constructive dismissal grievance under the ECA 1991 against Rentokil Ltd (a company incorporated in New Zealand, hereafter Rentokil NZ), and Rentokil Ltd (a company incorporated in the Republic of Fiji, hereafter Rentokil Fiji) was joined as a second respondent. Both companies had personnel in common. Both were (stand alone) whollyowned subsidiaries of Rentokil Group plc, which was registered in the United Kingdom. From 1991 to termination in 1993, Mr Clifford worked in Fiji on the business of Rentokil Fiji as the general manager. Prior to 1991, Mr Clifford, a New Zealand citizen, had worked in New Zealand for Rentokil NZ from 1982. Recruitment took place in New Zealand and discussions involved Rentokil NZ personnel. Documentation referred to Mr Clifford's

\footnotetext{
${ }^{27}$ Jardine Risk Consultants Ltd v Beal [2000] 1 ERNZ 405, at 411 (CA), the Employment Court Regulations 2000, reg. 31G(1) and the Employment Relations Authority Regulations 2000, reg. 19B.

${ }^{28}$ Musashi Pty Ltd v Moore [2002] 1 ERNZ 203 (EC) at 216, citing Court of Appeal dictum in Jardine Risk Consultants Ltd v Beal [2000] 1 ERNZ 405 (CA).
} 
secondment to Rentokil Fiji for a three year period to be followed by employment 'within NZ or elsewhere in the Group'. ${ }^{29}$

The Employment Court concluded that the system of law with the closest and most real connection to Mr Clifford's employment was that of New Zealand and ECA 1991 applied.

Redmond v DML Resources Ltd [1996] 1 ERNZ 448 (EC).

Mrs Redmond was appealing against remedies awarded by the Employment Tribunal under the Employment Contracts Act 1991 and DML Resources Ltd cross-appealed against the Tribunal's finding that Mrs Redmond had been unjustifiably dismissed on the basis that the Tribunal lacked jurisdiction because the proper law of the contract was Indonesian law.

DML Resources Ltd was a company based in New Zealand. The work was being performed for PT DML Resources (Indonesia). Mrs Redmond was domiciled in New Zealand. She was employed by DML Resources Ltd as the office manager at an office of DML Resources (Indonesia), carrying out the business of the Indonesian company. She was paid by DML Resources Ltd as the Indonesian company had not been incorporated at the time of her employment. She had not been employed by DML Resources Ltd before, unlike her husband who was on secondment to the Indonesian company. The employment was terminated after a few months. Her contract was negotiated in New Zealand and performed in the same circumstances as that of her husband. A large measure of control was exercised by DML Resources Ltd over Mrs Redmond's employment. Following a meeting between Mr Redmond and DML Resources Ltd's General Manager, Mrs Redmond was dismissed and had to leave Indonesia immediately. She returned to Auckland.

\footnotetext{
${ }^{29} 1995$ (1) ERNZ 407, 425 (EC).
} 
The court found that it could be inferred that the parties intended the law of New Zealand to apply to the Mrs Redmond's employment contract. It was found to be a 'compelling feature' ${ }^{30}$ that DML Resources Ltd did not contest that New Zealand law governed Mr Redmond's contract. The ECA 1991 applied.

\section{Jardine Risk Consultants Ltd v Beal [2000] 1 ERNZ 405 (CA)}

Jardine Risk Consultants Ltd was a New Zealand company, was part of a multinational enterprise and the original employer of Mr Beal. Mr Beal was employed in New Zealand from 1988 to the time that he agreed to secondment in Great Britain at the beginning of 1994. His contract was varied by an agreement that provided terms and conditions for the secondment. It was not argued that the employer changed. Mr Beal raised an action for wrongful dismissal in the Employment Court. The employer argued that the court did not have jurisdiction because the contract had been varied to make the applicable law that of England and that the forum conveniens was the United Kingdom. The Court of Appeal found that the applicable law was that of New Zealand, there being no express or implied variation as to the law of the original, operative contract. Although it was found that New Zealand was forum conveniens, the court noted that it was being increasingly recognised in other jurisdictions that employment disputes should be resolved in the jurisdiction in which the work is carried out. ${ }^{31}$

Royds v FAI (NZ) General Insurance Company Ltd [1999] 1 ERNZ 820 (EC)

\footnotetext{
${ }^{30}$ Redmond v DML Resources Ltd [1996] 1 ERNZ 448,466 (EC).

${ }^{31}$ Jardine Risk Consultants Ltd v Beal [2000] 1 ERNZ 405, 411. This dictum was applied by the Employment Court in the later case of Beale v Houghton [2002] ERNZ 110, 118 which found New Zealand to be forum non conveniens in circumstances where work was to be predominantly carried out in the northern hemisphere.
} 
This is a breach of contract case with related personal grievance applications. The first and second defendants sought declarations that the proper law of the contract was that of Papua New Guinea and that the court had no jurisdiction to determine the claims. The first defendant ('FAI (NZ)') was incorporated in New Zealand and carried on business there and elsewhere in the Pacific Islands. The second defendant ('FAI (PNG)') was incorporated in Papua New Guinea and was a wholly owned subsidiary of a company incorporated in Australia, which was in turn a wholly owned subsidiary of FAI Insurances Ltd, also incorporated in Australia. The defendants had personnel in common. Mr Royds was a New Zealand resident who commenced negotiations in New Zealand for a contract to work as general manager of the business of FAI (PNG). There was no express choice of law in the employment contract. The terms used in the employment contract had New Zealand characteristics; there was no evidence that the terminology was common to PNG; the form of the contract was a familiar New Zealand form; the salary currency was Kina, but linked to New Zealand currency; although the place of performance was PNG the contract was entered into and commenced in NZ, which was also the place of intermediate leave and the place from which control was exercised; repatriation at the end of the contract was to NZ; $\mathrm{Mr}$ Royds's domicile was New Zealand; it was intended that FAI(NZ) provided some form of continued employment in NZ; the negotiations did not refer to FAI (PNG); negotiations were with FAI (NZ); and Mr Royds did not notice the insertion of FAI (PNG) as employer into the contract. The court characterised the employment situation as that of a secondment and found the facts supported an inferred intention that New Zealand law was the proper law of the contract.

In the above cases, the employees had the protection of New Zealand law. They were employed by New Zealand companies, and the employer determined (and the employees 
agreed) that the work would be performed outside of New Zealand. The employer had control over the arrangement, which was temporary (except in the case of Mrs Redmond, who was not on secondment). The determining factor was the proper law of the employment contract.

These outcomes have the effect of bringing the employment relationship within the provisions of the New Zealand statute. However, the cases demonstrate a number of problems with the approach taken by the specialist institutions to situations with international connections. As discussed above, there is uncertainty about the jurisdiction of the specialist institutions where the proper law is not that of New Zealand. Also, it is arguable that the interpretation of what is now s 238 of the ERA 2000 is incorrect and that there should be a broad interpretation that removes the operation of conflict of laws rules in favour of the provisions of the Act in the light of the objects of the Act generally and Part 9 in particular. There is no express mention in the Act of the role of the proper law of the contract, the rules for determining the proper law or the consequences of a determination that New Zealand law is not the proper law of the contract. Resort to these conflict of laws rules is implicitly based on the right to dismissal protection being characterised as contractual without the basis for this characterisation being explained. Additionally, the rules have been developed and are applied from the perspective of business efficacy relying on express or implied choice or what it can be presumed 'reasonable businessmen would have decided' ${ }^{32}$ A business efficacy perspective was better suited to the objects of the ECA 1991. The ECA 1991 enacted into law '...the prevailing construction of the employment relationship as a matter of private

\footnotetext{
${ }^{32}$ See Royds v FAI (NZ) General Insurance Company Ltd [1999] 1 ERNZ 820 (EC) at 828, 830 citing 8 Halsbury's Laws of England ( $4^{\text {th }}$ ed) 863 regarding circumstances where there is no express or inferred choice of law.
} 
contract between two individuals. $^{33}$ The replacement of the ECA 1991 with the ERA 2000 was intended to signal a move from an emphasis on contractualism and economic efficiency back towards social justice and a recognition of the social costs of deregulation. ${ }^{34}$ The objects of the ERA 2000 include the promotion of mediation as the primary problem-solving mechanism and the reduction of judicial intervention as ways of building productive employment relationships. The Act speaks of employment agreements rather than contracts. It is explicit about its role as a counterweight to employer power by providing employees with collective and individual rights and protections. ${ }^{35}$

In seeking a resolution to their employment relationship problem, the parties in the above cases faced uncertainty, complexity and attendant cost. On the interpretation of the Employment Court, the provisions in the Employment Relations Act 2000 relating to personal grievances, the institutions, and contracting out were not changed in meaning from those in the Employment Contracts Act 1991 in any way that indicated that the legislature intended that the cases cited above should not continue to apply. Conflict of laws rules decided the issue of whether the employee was protected by New Zealand law in the case of Musashi Pty Ltd v Moore [2002] 1 ERNZ 203 decided after the commencement of the Employment Relations Act 2000.

Musashi Pty Ltd v Moore [2002] 1 ERNZ 203 (EC)

\footnotetext{
${ }^{33}$ The Hon. Margaret Wilson, then New Zealand Minister of Labour, 2000 Whitlam Lecture, Trade Union Foundation, delivered in Melbourne, Australia.

${ }^{34}$ See generally, P. Churchman 'Tracing the Arc of the Pendulum: The Regulation of Collective Bargaining in New Zealand (I) and (II)' [1991] NZLJ 306 and [1991] NZLJ 350, which takes the position that under the ECA 1991 New Zealand's employment relations system occupied the right (contractualist) end of the spectrum.

${ }^{35}$ Section 3(a)(ii).
} 
Musashi Pty Ltd was an Australian proprietary company registered in the state of Victoria, Australia. It was registered in New Zealand as an overseas company, and ran a New Zealand division.

Mr Moore was a New Zealand resident, hired in New Zealand. His work was performed wholly in New Zealand. He had a contract in a form which was used by the company irrespective of whether the employee was in Australia or New Zealand. The contract had features of Australian employment law, such as references to a 'Federal or State Award' and an 'Employment Separation Certificate'. Mr Moore signed the contract, acknowledging that he read it and fully understood it.

Mr Moore resigned and brought two claims before the Employment Relations Authority for unjustifiable disadvantage and unjustifiable constructive dismissal. The Authority determined that New Zealand law was the proper law of the contract and that New Zealand was the appropriate forum. Musashi Pty Ltd challenged the determination in the Employment Court.

Judge Colgan (now Chief Judge of the Employment Court) took the same approach as the court in Royds v FAI (NZ) General Insurance Co Ltd ${ }^{36}$ and found that by implication the parties had chosen that the law of the State of Victoria to govern the contract. ${ }^{37}$ Judge Colgan also held that New Zealand was the forum conveniens and that the Employment Relations Authority could determine Mr Moore's case. Section 238 was found to indicate that employment contracts entered into in New Zealand and performed in New Zealand 'should comply with the minimum legislative standards provided in [the Employment

\footnotetext{
${ }^{36}$ [1999] 1 ERNZ 820.

${ }^{37}$ Musashi Pty Ltd v Moore [2002] 1 ERNZ 203 at 214, 215, 216.
} 
Contracts Act 1991 and the ERA 2000]' ${ }^{38}$ The court did not go so far as to state that New Zealand law governed the contract; the law of Victoria applied. ${ }^{39}$ Mr Moore was not put to the expense of conducting his claims in a foreign forum, but there would be costs relating to evidence about the employment law of Victoria.

In a comparison of Victoria and New Zealand employment law, Judge Colgan noted other disadvantages for the employee. The right to protection from unjustified actions by an employer causing disadvantage to the employee was not available in Victoria. ${ }^{40}$ Judge Colgan also noted the absence of any provision under the applicable law for payment of compensation for humiliation, loss of dignity and injury to feelings available under $\mathrm{s}$ 123(c)(i) ERA 2000. ${ }^{41}$

Musashi illustrates the dangers of reliance upon an approach that permits a choice of proper law and/or determinations in overseas jurisdictions. ${ }^{42}$ It seems incongruous that a company operating in New Zealand could hire and employ in New Zealand a person who was subject to employment laws that were not those of New Zealand. Even if the extent of the protection afforded by conflict of laws rules is accepted as appropriate, the uncertainty and complexity of the law is incompatible with the objective of the ERA 2000 to provide speedy resolution of employment relationship problems at a point as close as possible to the parties

\footnotetext{
${ }^{38}$ Musashi Pty Ltd v Moore [2002] 1 ERNZ 203 at 218.

${ }^{39}$ Ibid 219.

${ }^{40}$ Ibid 212.

${ }^{41}$ Ibid, 213.

${ }^{42}$ Professor G. Anderson in 'Recent case comment' [2002] ELB No. 2, 37 further commented, 'What is surprising is that Parliament has not intervened to provide a legislative solution for cases such as this. It would seem a straightforward matter to provide that if any contract of employment provides for work to be performed in New Zealand the contract to be governed by New Zealand law. Suitable exceptions for temporary location in New Zealand or the like could be provided for. To allow otherwise opens up a potential loophole for the avoidance of New Zealand law and legislative policy.'
} 
to the problem. The ERA 2000 should cover work performed in New Zealand. It is arguable that the provisions of the ERA 2000 support an interpretation of s 238 that would mean the provisions governing dismissal protections would at least apply to a company operating in New Zealand which hires and employs staff in New Zealand. However, the statute should be amended to expressly govern cases with international connections to ensure that New Zealand law applies to such employees. The legislation should also go further and clarify the position of those who work overseas.

\section{A PROPOSAL FOR LEgISLATIVE CHANGE}

It is not suggested that the Employment Relations Act 2000 should be amended to expressly apply to any individual anywhere in the world. As was stated by Lord Hoffman in the case of Serco Ltd v Lawson ${ }^{43}$, '...usually such an exorbitant exercise of legislative power would be both ineffectual and contrary to the comity of nations.' To achieve protection from unjustifiable dismissal that is workable and appropriate in the global employment market, the ERA 2000 should be amended to include an equivalent provision to section 204 of the Employment Rights Act 1996 (UK) which states 'it is immaterial whether the law which (apart from this Act) governs any person's employment is the law of the United Kingdom, or of a part of the United Kingdom, or not.'

The adoption of a parallel New Zealand provision alone is not sufficient. A provision is needed that states that the Act applies to employees who work wholly or mainly in New Zealand. Additionally, the Act should expressly set out other categories of employees who are entitled to the protection of the Act to ensure that there is appropriate protection for employees outside of New Zealand without recourse to conflict of laws rules. The Act must

\footnotetext{
${ }^{43}$ [2006] UKHL 3, at paragraph 6.
} 
also state that where the specialist institutions have jurisdiction, questions of forum conveniens do not arise. To decide which categories of employee ought to be covered, it is helpful to look at the categories of employee identified by Lord Hoffman in the case of Serco Ltd $v$ Lawson. $^{44}$

\section{A. SERco Ltd V LaWSon; Botham V Ministry of Defence; Crofts and others V VETA LTD AND ONE OTHER ACTION}

The House of Lords had to identify the categories of persons covered by the right not to be unfairly dismissed on the proper construction of s 94(1) of the Employment Rights Act 1996 (UK). This Act has no express territorial limit on unfair dismissal protection: the court relied upon the general principle of construction that legislation is prima facie territorial. The parties disagreed as to the implied territorial limits of the Act. ${ }^{45}$ Lord Hoffman identifies three categories of employee covered by s 94(1): these are employees working in Great Britain at the time of dismissal (but not where the employee is on a casual visit), employees who are 'peripatetic', and employees who are 'expatriates'.

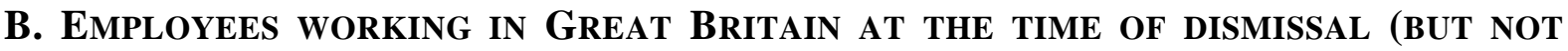
WHERE THE EMPLOYEE IS ON A CASUAL VISIT) ${ }^{46}$

Linden's analysis of Lord Hoffman's speech suggests that the key issue is not the amount of time spent working in Great Britain but the circumstances in which the employee comes to be working in Great Britain. ${ }^{47}$ This is the 'standard case'.

\footnotetext{
${ }^{44}$ [2006] UKHL 3 (UK).

${ }^{45}$ Ibid, [6].

${ }^{46}$ Serco Ltd $v$ Lawson and other cases [2006] UKHL 3 at [27].
} 


\section{EMPLOYEES WHO ARE 'PERIPATETIC'}

Peripatetic employees, ‘... such as airline pilots ... ${ }^{48}$ have a base in Great Britain determined by what was happening at the time of the dismissal rather than the terms of the original contract. $^{49}$ The base is the centre of operations for the employee and where work that involves performance in other countries begins and ends.

\section{EMPLOYEES WHO ARE 'EXPATRIATES'}

The expatriate employee is not working in Great Britain at the time of the dismissal, nor is there an identifiable base there at the time of dismissal. However, there is a sufficiently strong connection with Great Britain for the employee to be protected by the statute. Such a case would have the following characteristics:

The employer is based in Great Britain; and the employee is British or recruited in Britain; and a) the employee is posted abroad as a representative of the business conducted in Great Britain; or b) the employee works in a political or social British enclave abroad; or c) the employee is someone with an equally strong connection with Britain and British employment law. ${ }^{50}$

In the House of Lords analysis, it is the operation of the employment rather than the contract terms, and the connection of the operation of the employment with Great Britain rather than inquiries into the systems of law of other countries that determine protection from

\footnotetext{
${ }^{47}$ T. Linden 'Employment Protection for Employees Working Abroad' (2006) 35 ILJ 186, 189.

${ }^{48}$ Serco Ltd $v$ Lawson and other cases [2006] UKHL 3 at [28].

${ }^{49}$ Ibid [29].

${ }^{50}$ Ibid, [37] - [40].
} 
unfair dismissal. Giving protection to those working in Great Britain at the time of the dismissal reduces the potential for classes of 'haves' and 'have nots' within the same society; giving protection to those based in Great Britain serves the same purpose and in both cases ensures that workers are treated in accordance with British legislative policy. Any 'foreign factors' are immaterial if the work is done or based in Great Britain, and the outcomes are arguably those which an employee would expect (commonsense, not contract).

Amending the ERA 2000 to state that it is immaterial whether the law which (apart from this Act) governs any person's employment is the law of New Zealand or not, and which states that the Act applies to employees who work in New Zealand but not where the employee is on a casual visit, would give express protection from unjustifiable dismissal to employees in Mr Moore's position.

Employees based in New Zealand would be protected by adding a provision that peripatetic employees may pursue personal grievances for unjustifiable dismissal, irrespective of 'foreign factors' such as the employer being a foreign company that may have been set up for the express purpose to supply employees for an associated business (for example aircrew for the aircraft of another business). This provision would cover secondment situations. Although an employee may carry out another company's business from time to time, and that business may be indistinguishable from others covered by the foreign country's employment laws the definition of 'base' would be wide enough to cover the situations of Mr Clifford, $\mathrm{Mr}$ Royds, and Mr Beal. Despite expecting to be working away from New Zealand for a number of years and in possibly more than one country, the facts show a number of characteristics that would determine that they and the employer were based in New Zealand. Mrs Redmond's case is more difficult to distinguish from that of someone employed to work in a foreign country for a company that just happens to have a New Zealand connection. She was 
expressly and solely employed to work in Indonesia and had not worked for DML Resources Ltd before. She was not to be repatriated to New Zealand, although her contract was for a fixed term. It was unclear whether she was resident in New Zealand (although she was domiciled there). On the other hand, DML Resources Ltd largely controlled the employment. Her contract (like that of her husband) was negotiated in New Zealand and performed in the same circumstances as that of her husband. It is perhaps more arguable that, if protected at all, someone in Mrs Redmond's position is protected as an expatriate employee.

Expatriate employees should have protection from unjustifiable dismissal. These employees would not be working in New Zealand at the time of the dismissal, nor would there be a base in New Zealand at the time of dismissal. Lord Hoffman was clear that this category would be small. ${ }^{51}$ His 'gateways' to protection for the expatriate employee ought to be adopted. Mrs Redmond had an employer based in New Zealand. She was not recruited in Indonesia. She was not posted abroad in the sense of being a 'foreign correspondent on the staff of a [New Zealand] newspaper'. ${ }^{52}$ Nor did she work in a political or social [New Zealand] enclave without being integrated into the local society. She may be protected by being someone who has an equally strong connection with [New Zealand] and [New Zealand] law, given that the employer was based in New Zealand and exercised a great deal of control, including over the dismissal.

\section{Conclusion}

In the absence of universal, enforceable labour standards, the global employment market requires thought to be given to the scope and operation of domestic labour standards. The

\footnotetext{
${ }^{51}$ Serco Ltd $v$ Lawson and other cases [2006] UKHL 3, [36.]

${ }^{52}$ Ibid [38].
} 
New Zealand legislature should at least act to ensure that all employees working in New Zealand are protected by the same law that says dismissals must be for legal reasons and procedurally fair. Peripatetic and expatriate employees should also be protected. Despite the foregoing proposals, some will still be excluded who should be included (for example, some contractors, those left unprotected by the doctrine of sovereign immunity).

Nevertheless, Lord Hoffman's categories of protected employees provide a basis for statutory provisions that are less complex than the conflict of laws rules that are currently applied and will better inform employees and employers about protections against unjustifiable dismissal.

\section{JACQUELIN MACKINNON}

University of Waikato School of Law

New Zealand

jjm2@waikato.ac.nz 